\title{
Development and evaluation of operational performance of macaw fruits semi-mechanized harvester by means mechanical vibrations principle
}

\section{Desenvolvimento e avaliação de colhedora semi-mecanizada com o princípio de vibrações mecânicas para frutos de macaúba}

\author{
Christina Maria de Freitas Grupioni ${ }^{*}$; Fábio Lúcio Santos ${ }^{2}$; \\ Haroldo Carlos Fernandes 3 ; Domingos Sarvio Magalhães ValenteValente ${ }^{3}$; \\ Francisco de Assis de Carvalho Pinto ${ }^{4}$
}

\begin{abstract}
Macaw (Acrocomia aculeata) is a product of Brazilian socio-biodiversity and is an excellent source of oil for the cosmetics, food and fuel industry. One of the technical bottlenecks of macaw fruit production is the manual harvesting with rudimentary tools and the extractive system, which has a very large dependence on labor. The objective of this work was to develop the informational and conceptual design of a semi-mechanized harvesting system that can be used in adverse conditions of relief, also directed to the needs of family farmers. In this work the concept of a low cost macaw harvester is proposed, which works by the principle of mechanical vibrations, and is able to work efficiently in planted and natural plantations. From an adaptation of the Pahl and Beitz method for the development of machine designs, and the use of the evolution prototyping method, integration prototypes were constructed, which underwent a preliminary field test. Some modifications were made in portable coffee breakers, which constituted changes in the vibration signal generation system that were transmitted to macaw fruits at the head / plant interface. Only one of the built prototypes was considered effective and suitable for subsequent performance (product under patent registration). For the detailed design, CAD (Computer Aided Design) techniques were employed. Later, it was possible to observe the validation of efficiency of the macaw fruit harvest by the principle of mechanical vibrations. Under field conditions, field trials demonstrated that the average harvest efficiency for the proposed model with vibrating rods was $97.4 \%$ and the average harvesting capacity was $566.91 \mathrm{~kg} \mathrm{~h}^{-1}$.
\end{abstract}

Key words: Machine design. Harvesting. Agricultural mechanization. Family farming.

\section{Resumo}

A macaúba (Acrocomia aculeata) é um produto da sociobiodiversidade brasileira e é uma excelente fonte de óleo para a indústria cosmética, de alimentos e de combustíveis. Um dos gargalos técnicos da produção dos frutos da macaúba é a colheita feita de forma manual com ferramentas rudimentares e no sistema extrativista, que tem dependência muito grande de mão de obra. Objetivou-se com o presente trabalho desenvolver o projeto informacional, conceitual e detalhado de um sistema semi-mecanizado

${ }^{1}$ Enga Agra $^{\mathrm{a}}$, Discente Mestrado, Programa de Pós-Graduação em Engenharia Agrícola, Universidade Federal de Viçosa, UFV, Viçosa, MG, Brasil. E-mail: chrisgrupioni@gmail.com

2 Prof. M.e, Universidade Federal de Lavras, UFLA, Lavras, MG, Brasil. E-mail: ffabiolss@gmail.com

${ }_{3}^{3}$ Profs. Mestres, Universidade Federal de Viçosa, UFV, Viçosa, MG, Brasil. E-mail: haroldo@ufv.br; sarvio.valente@gmail.com

${ }^{4}$ Prof. Ph. D., UFV, Viçosa, MG, Brasil. E-mail: fcarvalhopinto@gmail.com

* Author for correspondence 
de colheita que possa ser utilizado em condições adversas de relevo. Foi proposto o conceito de um mecanismo colhedor de macaúbas, de baixo custo, que funciona pelo princípio de vibrações mecânicas, e é capaz de trabalhar com eficiência em lavouras plantadas e maciços naturais. A partir de uma adaptação do método de Pahl e Beitz para desenvolvimento de projetos de máquinas, e a utilização do método de prototipagem de evolução, foram construídos protótipos de integração, que passaram por ensaio preliminar de campo. Foram realizadas algumas modificações em derriçadoras portáteis de café, que se constituíram em alterações no sistema de geração de sinais de vibração e foram transmitidos aos frutos de macaúba, na interface cabeçote/planta. Apenas um dos protótipos construídos foi considerado eficaz e adequado para realização posterior de avaliação de desempenho (protegida por meio de depósito de pedido de patente junto ao Instituto Nacional da Propriedade Industrial - INPI, sob o n. ${ }^{\circ}$ BR 10 2017010814 7). Para o projeto detalhado foram empregadas técnicas de CAD (Projeto Auxiliado por Computador). Posteriormente, foi possível observar a validação de eficiência da colheita dos frutos de macaúba pelo princípio de vibrações mecânicas. Nas condições em que ocorreram, os ensaios de campo demonstraram que a média da eficiência de colheita para o modelo proposto com varetas vibratórias foi de $97,4 \%$ e a média da capacidade de colheita foi de $566,91 \mathrm{~kg} \mathrm{~h}^{-1}$.

Palavras-chave: Agricultura familiar. Colheita. Mecanização agrícola. Projeto de máquinas.

\section{Introduction}

The macaw (Acrocomia aculeata)-also called grugru palm, macaúba palm, coyol palm, and macaw palm-is a palm native to Brazil; it is a product of Brazilian biodiversity, and is an excellent source of oil for the cosmetic industry and food and fuel. It has a high energy efficiency and can grow in soils of low agricultural vocation in the tropics and subtropics (BOHN, 2009). It is a raw material with great potential to diversify the Brazilian energy matrix and ensure food security from productive consortia and agroforestry systems with focus on food, wood, and energy from productive arrangements that strengthen the basis of family farming and promote the well-being of communities.

The harvest of the fruit is one of the bottlenecks in the production chain of macaw palm, as there is no commercial equipment available and adapted to mechanized harvesting of the fruit. This is done by extraction, which is quite an exhausting job, is expensive, and provides low yield. Currently, the fruits are collected from the ground (CARVALHO et al., 2011) after they are either naturally detached from the bunches or other rudimentary techniques are used to induce fruit detachment. Other strategies have been tried, such as the use of scythes connected to bamboo stems to cut the bunches and, occasionally, installation of fixed collectors next to each palm tree (MONTOYA et al., 2015).

As for the design of machines for the harvesting of macaw fruits, it is believed that a potential principle for the development of mechanical harvesting systems is based on the use of mechanical vibrations (VILLAR et al., 2017). This is possible since the fruits show uniformity of development throughout the bunch. This principle is used in different crops, such as coffee, olive, tomato, pistachio, and jatropha (SANTOS et al., 2010; COELHO et al., 2016; SILVA et al., 2015; CUNHA et al., 2014; VERONESI et al., 2012).

This principle could allow the fruits of macaw palm to be harvested at an appropriate maturation point. This would provide the extraction of better quality oil and increase the operational capacity of the process, minimizing any problems relating to the shortage of skilled labor that has plagued Brazilian agriculture in various regions.

As currently practiced, the harvest has proved to be unfeasible for large-scale production of pulp oil with competitive quality compared to other oil sources. In the state of Minas Gerais, for example, the agro-industrial production capacity is higher than the regional raw material supply capacity. In order to better meet this demand, the objective 
was to develop the project and build a portable, inexpensive macaw fruit picking device that works by the principle of mechanical vibrations that can be used in adverse terrain conditions, attend to the diverse realities operating in the field, both in planted crops and in sustainable exploitation of the native growth of macaw.

\section{Material and Methods}

The macaw harvester mechanism was designed and built, using a methodology composed of two stages: development of the concept of the harvester mechanism and evaluation of prototypes.

Step 1: Development of the concept of the harvester mechanism

The need to harvest the fruits of the macaw in both flat and hilly terrain was taken into account. For the development of the project, an adaptation of the methodology described by Pahl and Beitz (2005) was used, which was divided into the following stages: informational design; clarification of tasks; conceptual design; preliminary project; and detailed design.

\section{Informational design}

A literature review was undertaken in all phases of the study. The search for information also occurred through visits and informal conversations with representatives of companies and cooperatives that process the fruits of the palm tree. These conversations were important to determine the requirements, in line with the actual need of the macaw production chain today.

\section{Clarification of the task}

Through the use of checklists, analogies, and the brainstorming method (GODOY, 2001), the needs, specifications, and functions of the device were defined. The needs were converted into requirements, and these were discriminated from the standpoint of the literature and the producer of macaw as indispensable or desirable. The tasks of the harvester were established and detailed, taking into account the design requirements that a harvester will need to meet in order to harvest the macaw. The main constraints involved in solving the problem were also considered.

At first, the need to harvest macaws was converted into design specifications, according to the requirement list (Table 1). A weight was assigned representing the importance of each requirement, and the characterization of each item was performed (total weight $=1.0$ ). The weighting was performed and calibrated by the team, in successive analysis, through brainstorming. In order to avoid the redundancy of the requirements, needs that have the same meaning were searched, joining the items.

The main constraints of the project were detected and are as follows: limited time for project development, limited financial resources, lack of autonomy to manage the resource by the funder, and the equipment and manufacturing processes available to build a viable prototype. Constraints interfere with all project decision steps.

Through the computationally-implemented Mudge Diagram, the hierarchy of requirements was obtained by means of a paired comparison (NICKEL et al., 2010). A weight and value were assigned to each degree of importance, as well as its respective letter: less important $(\mathrm{A}=1)$; moderately important $(\mathrm{B}=3)$; much more important $(\mathrm{C}=5)$. For each comparison, the question was asked: Which requirement is the most important and how much is it more important than the other? 
Table 1. List of requirements, weights, and their characterization.

\begin{tabular}{|c|c|c|}
\hline Requirements & Weight & Characterization \\
\hline Mechanical strength & 0.10 & $\begin{array}{l}\text { Resistant components in accordance with the operational capacity, } \\
\text { enabling its use for various crops without the need of replacement. }\end{array}$ \\
\hline Adequate harvesting capacity & 0.12 & $\begin{array}{l}\text { Possess higher harvesting capacity than manual harvesting, which is } \\
37.5 \mathrm{~kg} \mathrm{~h}^{-1} \text { (BRASIL, 2014). }\end{array}$ \\
\hline Low drive power & 0.05 & Require low energy to move the mechanisms. \\
\hline Be easy to adjust & 0.07 & $\begin{array}{l}\text { The operation must be intuitive, so that operators with low qualification } \\
\text { and lesser degree of instruction are able to use it. }\end{array}$ \\
\hline Easy maintenance & 0.05 & $\begin{array}{l}\text { Regarding the ease of lubrication and assembly and disassembly of the } \\
\text { device, without the need for a large number of tools or special tools; } \\
\text { minimizing costs, optimization of manufacturing and maintenance. }\end{array}$ \\
\hline Easy to assemble & 0.07 & A few parts, few tools involved \\
\hline Portability (light/retractable) & 0.09 & $\begin{array}{l}\text { Mass and geometry compatible with the transport capacity on sloping } \\
\text { terrain; }\end{array}$ \\
\hline Easy transportation of fruits & 0.07 & Require minimal effort in the logistics of transporting fruits \\
\hline Low production cost & 0.06 & $\begin{array}{l}\text { The acquisition of the machine must be viable for harvesting small } \\
\text { areas and the price has to be compatible with the operational capacity. }\end{array}$ \\
\hline $\begin{array}{l}\text { Commonplace manufacturing } \\
\text { processes }\end{array}$ & 0.07 & $\begin{array}{l}\text { Related to the feasibility of manufacturing the machine in workshops } \\
\text { and locksmiths, using common manufacturing and assembly processes. }\end{array}$ \\
\hline Use of standardized components & 0.10 & $\begin{array}{l}\text { Optimization of production and maintenance; material easily found in } \\
\text { the market. }\end{array}$ \\
\hline Ergonomics & 0.10 & $\begin{array}{l}\text { Require minimal effort in the harvesting operation, provide proper } \\
\text { posture to the operator. Meet legislation on transmissibility of vibrations } \\
\text { and noise. }\end{array}$ \\
\hline Security & 0.10 & $\begin{array}{l}\text { Adequate protection of risky moving parts should be provided, without } \\
\text { sharp edges. According to the current legislation for noise and vibration } \\
\text { at work. }\end{array}$ \\
\hline Minimal environmental impact & 0.05 & Follow the guidance of environmental legislation. \\
\hline
\end{tabular}

\section{Conceptual design}

From the definitions of the tasks and the design requirements, a structure of the functions of the device was established and, sequentially, the search for principles of solution to fulfill all the functions. A morphological matrix (PAHL; BEITZ, 2005) was elaborated to find solutions for each function of the harvester mechanism. The solution principles found in the morphological matrix were combined, and, from the combinations, relative weights and scores related to use, aesthetics, weight, costs, maintenance, reliability, safety, national and international standards, ergonomics, and environmental issues were established. These parameters were obtained by a technical and economic analysis in order to choose the most appropriate global solution for the work scope. A viability judgment, based on the project team's experience, was used to select the concept that best met the project specifications, (BERTOLDI, 2013). The result of this phase was the basic concept of the device, that is, the definition of the operating principles of the harvesting system. 


\section{Preliminary design}

To better understand which approach to follow in the conception and physical viability of the device and demonstrate the functionality of the design, we used the prototyping integration method (YANG; EPSTEIN, 2005; HOUDE; HILL, 1997). A disposable, non-functional prototype was initially built with cardboard and Styrofoam, which helped establish the geometry, notions of dimensions, and adaptation to the original head. Subsequently, an evolutionary prototype was built, which went through iterative processes of construction and evaluation (SOMMERVILLE, 2010) until reaching a form appropriate for the morphology and architecture of the macaw palm bunches.

\section{Detailed design}

At this stage, the geometries and dimensions of the constituent parts of the final prototype assemblies were elaborated from the selected global solutions. The parts were generated in a CAD (Computer Aided Design) platform, which was also used for virtual assembly of the two prototypes in development, for guidance in the constructive process. The materials were characterized, and a list of parts and materials was elaborated.

\section{Step 2: Evaluation of prototypes}

Two field trials were conducted in which two and five bunches of randomly chosen macaw palm trees were employed for each of the tests. The tests were performed at the Germplasm Bank (BAG), which is located at the experimental farm of the Federal University of Viçosa, municipality of Araponga, MG. The first test aimed to provide guidance about the best way to operate the machine, the effect of the factors of acceleration (continuous variable), and position of the harvesting head (transversal and longitudinal) with respect to the efficiency of detachment of the macaw palm fruits.
During the execution of the trial, the hanging load of the plants of each experimental unit (a bunch), composed by the sum of the number of fruits harvested $(n c)$ and not harvested (np), was determined. The efficiency of the harvest $(\mathcal{E})$, expressed in percentage, was determined based on the ratio between the number of fruits harvested and the hanging fruit load present in the bunch (equation 1).

$$
\varepsilon=100 *\left(\frac{n c}{n c+n p}\right)
$$

For the second trial, the number of fruits detached from the bunch, the number of fruits that remained in the bunches, and the time spent in the harvest(s) were recorded. Thus, it was possible to determine the harvesting efficiency and harvesting capacity $(C c)$, expressed in number of fruits harvested $\mathrm{h}^{-1}$, characterized by the relation between the number of fruits harvested $(n c)$ and time (tc), in seconds, spent during the process (equation 2).

$$
C c=3600 *\left(\frac{n c}{t c}\right)
$$

The macaw palm fruits with visible damage caused due to harvesting with the prototype were recorded. The damage to the macaw fruits was classified as mild or severe. Mild damages resulted in damage on the epicarp of the fruit without promoting its breakage. Severe damages damaged the epicarp, causing the exposure of the mesocarp of the fruit.

\section{Results and Discussion}

\section{Clarification of the task}

Figure 1 presents the results for the hierarchy of requirements, via the Mudge method (NICKEL et al., 2010), which were determined from the sum of points weighted by the weights (Table 1). 
The result demonstrated by the Mudge diagram (Figure 1) indicates that the requirement with the highest score was "harvesting capacity exceeding manual," which, in fact, represents the motivation for starting the project. The second position "mechanical strength" stresses the importance of the mechanical design of the device since the final performance of a device is correlated with the material properties of the components and the correct dimensioning of the device elements and mechanisms. In the third and fourth position are "safety" and "ergonomics" since, regardless of other characteristics, the device needs to guarantee an operation with the minimum of risks for the operators, with the minimum of effort in the operation, and respecting the legislation in force for work ergonomics.

Figure 1. Determination of the requirements relating to the macaw harvesting device (Mudge method).

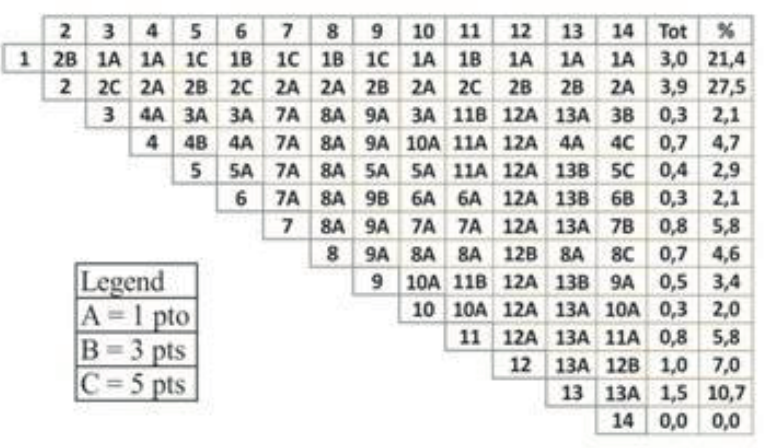

The item "low cost" reached an intermediate position of importance. However, it is directly related to other requirements such as the use of standardized components and ordinary manufacturing processes which also facilitate and reduce production costs. On the other hand, the requirements "easy maintenance," "easy regulation," and "low drive power" include economy during the use of the product (Table 1). Added to the weights of these requirements, one must focus on economic solutions, for production and for use, as this will be accessible to the small family farmer. This could curb internal migratory flows to contribute to fix the families in the field since the use of the macaw palm oil for biodiesel production with the participation of family farming would increase the demand for this plant and would help promote the socioeconomic development of many needy regions in the country, through job and income generating programs, contributing to the eradication of poverty.

\begin{tabular}{c|l|c}
\hline Item & \multicolumn{1}{|c}{ Requirements } & Classification \\
\hline 2 & Harvest capacity greater than manual & 1 \\
1 & Mechanical strength & 2 \\
13 & Safety & 3 \\
12 & Ergonomics & 4 \\
11 & Use of standard components & 5 \\
7 & Portability (light retractable) & 6 \\
4 & Easily adjusted & 7 \\
8 & Easy transport of fruits & 8 \\
9 & Low production costs & 9 \\
5 & Easy maintenance & 10 \\
3 & Low drive power & 11 \\
6 & Easy to assemble & 12 \\
10 & Commonplace manufacturing processes & 13 \\
14 & Minimal environmental impact & 14 \\
\hline
\end{tabular}

The requirement "portability (light/retractable)" refers, again, to the careful selection of the material since weight reduction is a universal attribute for mobile equipment, and the mechanical resistance associated with low weight and cost of production provides guidance for a thorough choice. The requisite "minimum environmental impact," although initially considered important, was not a fundamental requirement when compared with others for the current context of development of this harvesting device.

The Mudge diagram was shown to be a good tool to clarify ideas about the requirements given that the confrontation between requirements, two by two, revealed a greater clarity and discernment about the relevance of each item. The result represented the team's priorities for concept development in order to focus on genuinely basic issues in order to achieve the objective of the experiment and to meet a product expectation that can meet the need to 
harvest macaw palm without depending totally on the personal opinion of team members (BERTOLDI, 2013).

\section{Conceptual design}

From the identification of the simplest subfunctions, it was possible to elaborate the structure of basic functions of the harvesting device. The overall function that the machine must perform is to harvest macaw palm fruit. This broad function unfolds in releasing the fruits and collecting/storing the fruits. For such, it is necessary to receive power from a power source which will trigger the mechanisms. The operator operates a signal that will convert the energy from the power source into mechanical vibrations that, upon accessing the cluster, releases the fruits. That is, the operator interacts with the device, providing signals, adjustments, drives, and monitoring throughout the harvesting process. The result of this set of actions will be harvested macaw palm fruits.

Using the morphological matrix method (PAHL; BEITZ, 2005), the solution principles were assigned to each sub-function, identified through the function structure, as shown in Table 2. The solution principles give the final product its shape, so this is a very important phase of the project. These solution principles were later combined-always seeking to meet the requirements and respecting the design constraints. The morphological matrix was worked dynamically and interactively with the study of the structure of the functions. That means that, as the structure was designed, one could already imagine possible solutions within the morphological matrix.

The analyses to obtain combinations of viable solutions to be constructed were based on technical and economic criteria laid down in the requirement list. Specific weight requirement was used as a criterion to consider the scores and evaluate the more relevant solutions. The possibilities of viable combinations were later pooled, and the viability judgement was based on the experience of the team and constraints of the project.

The energy source was analyzed in a general way, and resulted it opting for an internal combustion engine because it is more accessible in the region where the study was conducted. Both portable 2-stroke engines (2S) and 4-stroke engines (4S) meet the need and objective of the work. It was considered that the detachment of the fruits of the rachis and rachilla saves transportation and storage space. The development of the device at the interface with the plant was analyzed from the morphology and architecture of the plant. It was found that the arrangement of the stems needed to be adapted to efficiently fit the distribution of the fruits in the cluster. It was assumed, for the harvesting head mechanism, to use commercially available and possibly standardized components.

The collection of the fruit is an essential item to increase the operational capability of the system, since the collection on the ground of the fruits or bunches is extremely costly from the point of view of time and operator fatigue. The use of ground canvas is indicated as an interesting, but provisional, solution, since it reduces effort and the collection of fruits compared to the direct collection of fruit on the ground. For coffee, for example, a form of harvesting widely used in Brazil is the strip harvesting on canvas (EMATER, 2016). One option raised by the team (Table 2) was the development of a trimmer, similar to an inverted umbrella, which was not implemented for the preliminary tests, being indicated as a promising option for complementation of the system. 
Table 2. Morphological matrix with the solutions for each sub-function.

\begin{tabular}{|c|c|c|c|c|c|c|}
\hline \multicolumn{7}{|c|}{ Solutions } \\
\hline & Sub-Functions & 1 & 2 & 3 & 4 & 5 \\
\hline 1 & Power Source & Battery & $\begin{array}{c}\text { Intemal combustion engine } \\
\qquad 8\end{array}$ & $\begin{array}{l}\text { Pneumatic } \\
\text { (C) }\end{array}$ & & \\
\hline 2 & Access to height & Extender & Telescopic Ladder & $\begin{array}{c}\text { Pantographic } \\
\text { Lift } \\
\text { \& } \\
\text { zi⿺ }\end{array}$ & 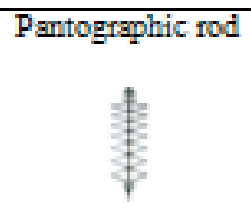 & \\
\hline 3 & $\begin{array}{l}\text { Attaching to } \\
\text { harvest }\end{array}$ & $\begin{array}{l}\text { Embrace the } \\
\text { trunk }\end{array}$ & Embrace trunk (jaws) & $\begin{array}{l}\text { Embrace } \\
\text { rachis }\end{array}$ & $\begin{array}{l}\text { Directly on } \\
\text { rachillse }\end{array}$ & $\begin{array}{l}\text { Head } \\
\text { Plant } \\
\text { (7) }\end{array}$ \\
\hline 4 & Detach fruits & $\begin{array}{l}\text { Lateral } \\
\text { movement }\end{array}$ & Double/ateral movement & $\begin{array}{l}\text { Open/close } \\
\text { movement }\end{array}$ & $\begin{array}{l}\text { Double rods/ } \\
\text { open/close } \\
\text { movement }\end{array}$ & \\
\hline 5 & Controller Device & & & $\begin{array}{l}\text { Position } \\
\text { Sensor } \\
\text { P }\end{array}$ & Remote Control & \\
\hline 6 & Collect fruits & $\begin{array}{l}\text { Inverted } \\
\text { Umbrella }\end{array}$ & Cloth on the ground & $\begin{array}{l}\text { Side } \\
\text { Trimmer } \\
\text { vs }\end{array}$ & Baskets & \\
\hline 7 & $\begin{array}{c}\text { Transporting the } \\
\text { device }\end{array}$ & Backpack & Operator am & $\begin{array}{l}\text { Chassis with } \\
\text { tripod } \\
\end{array}$ & $\begin{array}{c}\text { Chassis with two } \\
\text { wheels }\end{array}$ & \\
\hline
\end{tabular}

The visual controller device was chosen for economic issues in order to meet the item "low cost" from the list of requirements. In relation to access to the plant, the extender was the best evaluated due to the fact that similar models for other purposes already exist on the market. Although this limits the use of the equipment in higher plants, it was considered a reasonable solution to operate with plants with bunches up to $4 \mathrm{~m}$ high. From the considerations addressed, we conducted a feasibility trial (BERTOLDI, 2013), and, in a consensual manner, two combinations were defined to be constructed and tested in the field.

\section{Preliminary design: evolutionary prototyping}

From the list of requirements, the Mudge diagram, and the morphological matrix, the prototypes were manufactured from traditional manufacturing techniques such as machining, turning, and welding. Tangible prototypes were built in order to explore design alternatives before selecting a final project. 
Thus, the popular empirical method of finding solutions to bottlenecks in the field was combined with sophisticated methods of project design.

Initially, the head used for coffee harvest was evaluated. It was found that this device did not allow a satisfactory result for fruit detachment and advancement in the trials of operational capacity. This was due to the lack of consonance between the architecture of the macaw bunch and the design of the stems of the head of the coffee stripper. The lateral movement used to harvest the coffee also did not demonstrate efficiency considering the architecture of the macaw bunch.

A P1 prototype (Figure 2) was constructed, in which the concept was considered: the morphology and architecture of the macaw bunch and the design of the base of the original head (static support structure) of a mechanical coffee stripper. The P1 prototype allowed a preliminary test in macaw bunches. The test indicated that it is possible to harvest macaw bunches using the principle of vibration.

Figure 2. Evolutionary prototyping: P1 head to the left and P2 head right.

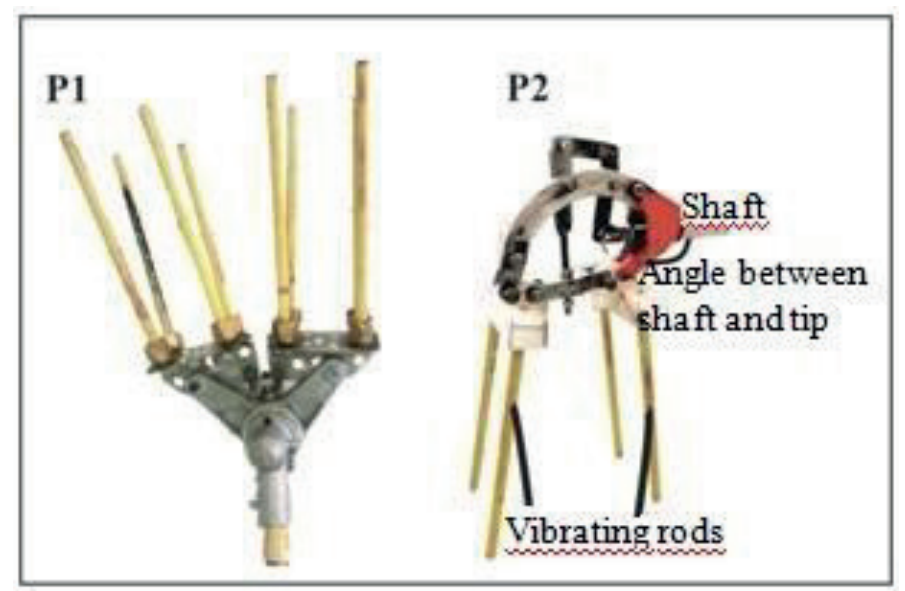

A second prototype, called the $\mathrm{P} 2$ prototype (Figure 2), was built. This device was not successful in field operations, being discarded immediately after the first attempts to harvest in the field. From the proposed mechanisms, when contacting the rachilla, the machine was observed not able to maintain the vibratory movement of the rods, being considered not suitable for the operation.

Although primarily the P1 prototype was constructed to verify the essential functionality of the design, i.e. if the principle of mechanical vibration harvesting was satisfactorily, it was also used for analysis of usability and appearance. Therefore, since it serves multiple purposes, it can be classified as an integration prototype (HOUDE; HILL, 1997). The prototype can also be classified as evolutionary (SOMMERVILLE, 2010), because it was iterative throughout the development of the project.

\section{Preliminary assessment}

\section{Preliminary field test 1}

The field trial 1 indicated ways of how and in which contexts a portable mechanical harvester of macaw palm could be used and developed. It was observed that there is a difference between the continuous acceleration and variable acceleration of the P1 prototype for the efficiency of the harvest. When the bunch has a high, bulky drop-down load, the beginning of the detachment of the fruit takes longer to start. 
From the observation of the harvest data in two macaw bunches (Table 3) collected from the preliminary field test with the $\mathrm{P} 1$ prototype, it was possible to establish goals for improving the concept of the macaw harvester.

Table 3. Results of the first field trial, in Araponga, MG.

\begin{tabular}{lcc}
\hline Characteristics & Bunch 1 & Bunch 2 \\
\hline Height from the ground (m) & 1.51 & 1.59 \\
Hanging load (number of fruits) & 56 & 160 \\
Harvested (number of fruits) & 52 & 149 \\
Non-harvested (number of fruits) & 4 & 11 \\
Harvest efficiency (\%) & 92.86 & 93.13 \\
\hline
\end{tabular}

The harvest efficiency, in the first analysis, would justify the continuation of tests for the improvement of the concept. However, the mass of the harvesting head $(3.97 \mathrm{~kg})$ compromised the work due to operator fatigue. Considering this scenario, the need to reduce the mass of the head was decided, with reference to portable mechanical strippers commercially available for coffee, in which the harvesting heads have a mass of approximately $2.0 \mathrm{~kg}$. The distribution and the angles of the rods needed to adapt, allowing a better angle of attack of the harvesting head, in order to allow an effective interaction with the rachilla. With regard to ergonomic aspects, it was observed that this project did not meet the ergonomic requirements for the job and needed improvement.

\section{Preliminary field test 2}

From the adjustments and reconfigurations carried out on the P1 prototype, a second test was carried out to evaluate the performance of the modified mechanisms. The harvesting efficiency of the machine was evaluated, as well as its harvesting capacity in relation to the hanging fruit load in the bunch (Table 4).

Table 4. Harvesting capacity and harvest efficiency of preliminary field test.

\begin{tabular}{cccccccc}
\hline Ref & Harvest Time (s) & Fruits harvested & $\begin{array}{c}\text { Non- } \\
\text { harvested } \\
\text { fruit }\end{array}$ & $\begin{array}{c}\text { Hanging } \\
\text { Load }\end{array}$ & $\begin{array}{c}\text { Cap. } \\
\text { (no. fruits/h) }\end{array}$ & $\begin{array}{c}\text { Cap. * } \\
(\mathrm{kg} / \mathrm{h})\end{array}$ & Ef (\%) \\
\hline 1 & 38 & 124 & 0 & 124 & 11747 & 483.9 & 100.0 \\
2 & 72 & 340 & 2 & 342 & 17000 & 700.2 & 99.4 \\
3 & 92 & 391 & 5 & 396 & 15300 & 630.2 & 98.7 \\
4 & 104 & 368 & 20 & 388 & 12738 & 524.7 & 94.8 \\
5 & 79 & 264 & 16 & 280 & 12030 & 495.5 & 94.3 \\
Mean & 77 & 297 & 9 & 306 & 13763 & 566.9 & 97.0 \\
\hline
\end{tabular}

*Estimated from the mean macaw palm fruit weight of $41.9 \mathrm{~g}$ (VELLOSO, 2016) 
Replicate 5 yielded a harvesting capacity of $495.5 \mathrm{~kg} \mathrm{~h}^{-1}$ and the lowest efficiency, which was $94.3 \%$. The lowest value obtained in the trials ( 483.9 $\mathrm{kg} \mathrm{h}^{-1}$ ) obtained 12-fold more harvest capacity than the estimated manual harvest of macaw fruits, of $37.5 \mathrm{~kg} \mathrm{~h}^{-1}$ (BRASIL, 2014).

\section{Mechanical damage to the fruits}

Some fruits suffered mechanical damage when impacted. The damage was classified as minor damage-when there are risks to the epicarp that do not break the shell-and severe damage-when the impact is enough to break the epicarp, generating injury in which there is exposure of the macaw pulp. Table 5 shows the results for damage occurrence in the field trials.

Table 5. Occurrence of mechanical damage in the macaw fruit harvesting field trial in Araponga, MG.

\begin{tabular}{cccccc}
\hline Rep & $\begin{array}{c}\text { Fruits } \\
\text { harvested }\end{array}$ & $\begin{array}{c}\text { Fruit with mild } \\
\text { damage }\end{array}$ & $\%$ & $\begin{array}{c}\text { Fruit with severe } \\
\text { damage }\end{array}$ & $\%$ \\
\hline 1 & 124 & 0 & 0.0 & 2 & 1.6 \\
2 & 340 & 73 & 21.3 & 37 & 10.8 \\
3 & 391 & 71 & 17.9 & 18 & 4.5 \\
4 & 368 & 108 & 27.8 & 86 & 22.2 \\
5 & 264 & 84 & 30.0 & 22 & 7.9 \\
Mean & 297 & 67 & 19.4 & 33 & 9.4 \\
\hline
\end{tabular}

It should be noted that the mean percentage of severe damage was $9.4 \%$ while the maximum of severe damage was $22.2 \%$. In the case of corn, the percentage of damage was around $25 \%$ with an automatic harvester, and, in the case of a harvester attached to a tractor, more than $50 \%$ of the grains displayed severe damage (MANTOVANI, 2010). In case of mild damage, as there was no exposure of the mesocarp, significant changes in the characteristics and quality of the fruit are not likely. This is expected given that the fruit does not remain in contact with the soil, being collected immediately and transported to the post-harvest processing. However, when the damage is severe, the mesocarp is vulnerable to microorganisms, because it is exposed, which can compromise the quality of fruit and their oils (MOTA et al., 2011).
The preliminary results obtained in the trials for harvesting efficiency, harvesting capacity, and damage to macaw fruit during harvesting corroborate the hypothesis that the use of mechanical vibrations is an effective principle for harvesting this fruit.

\section{Detailed Design}

From the choice of a concept that encompasses the best characteristics observed in the field during the preliminary tests, the preliminary layout and components of the macaw fruit harvester were identified (Figure 3, Figure 4, Table 4). 
Figure 3. Layout of the concept selected for the macaw palm harvester.

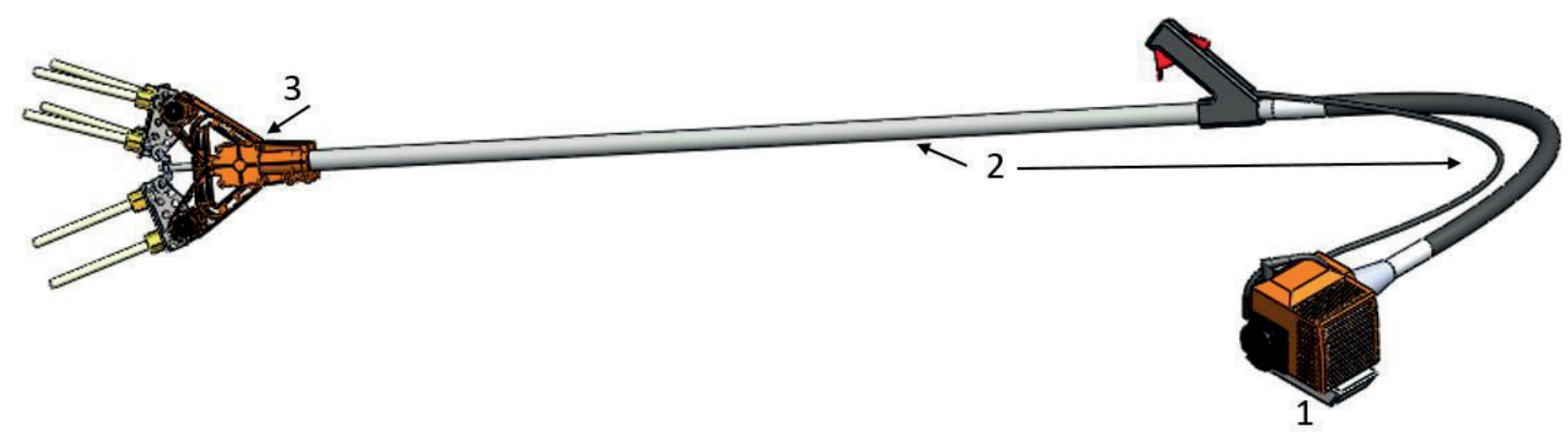

Figure 4. Components of the support and rods of the macaw harvester mechanism.

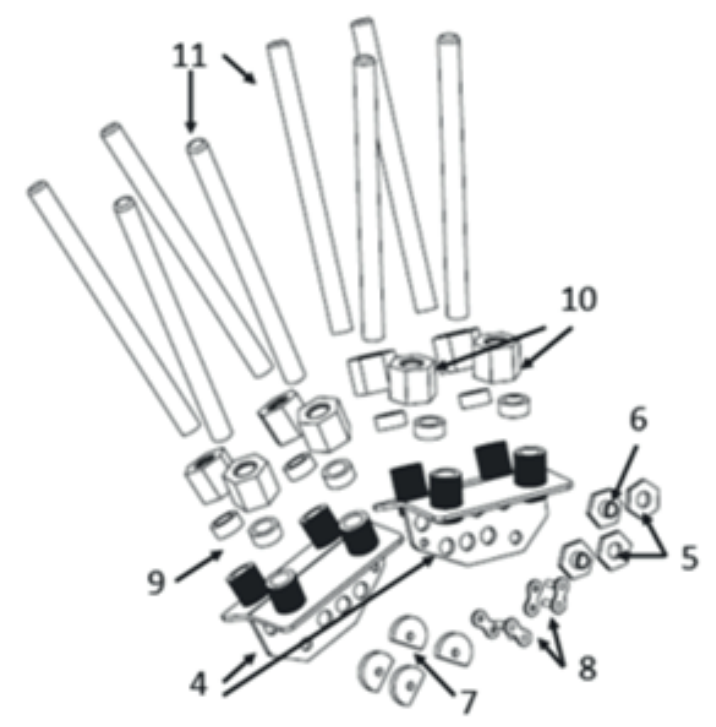

The final concept of the harvesting device consists of (1) a power supply unit, which may be a backpack or sidepack gasoline run internal combustion engine, $4 \mathrm{~S}$ or $2 \mathrm{~S}$, with a minimum power of 0.88 $\mathrm{kW}$ and 8500 to $11700 \mathrm{rpm}$ working rotation, with a motor power transmission system to the rods; (2) a tubular rod of at least 1.50 meters, being possible to use larger tubular rods; (3) a harvesting head that is a device for the plant/device interface adapted to the morphology of the macaw fruit bunch, with eight vibrating rods, that act directly in the rachillae of the bunches, causing the detachment of macaw fruits. The proposed harvesting head uses the principle

\begin{tabular}{|c|c|c|}
\hline Item & Description & $\begin{array}{c}\text { Quantity } \\
\text { (unit) }\end{array}$ \\
\hline 1 & Portable 2S or 4S engine & 1 \\
\hline 2 & Power transmission system & 1 \\
\hline 3 & Head & 1 \\
\hline 4 & Supporting rods & 2 \\
\hline 5 & Supporting nuts & 2 \\
\hline 6 & Supporting lock-nut & 2 \\
\hline 7 & Nylon washer & 4 \\
\hline 8 & Complete link & 2 \\
\hline 9 & Nylon stopper & 8 \\
\hline 10 & Rod nut & 8 \\
\hline 11 & Fiberglass rods & 8 \\
\hline
\end{tabular}

of mechanical vibrations, in which the vibrational energy is transmitted to the fruits from a movement along the rachis, the rachillae being attacked directly by the stems. The device should operate in a frequency range of 23 to $24 \mathrm{~Hz}$ or 37.5 to $39 \mathrm{~Hz}$, and an amplitude of 21 to $22 \mathrm{~mm}$. The attack on the rachilla favors the transmission of energy to the system and promotes the detachment of the fruits.

A virtual assembly of the selected design was elaborated, with the geometry and dimensions of the constituent pieces of each being detailed (Figure $5)$. 


\section{Conclusions}

Under the conditions of the tests performed, the results allowed the following conclusions:

The principle of mechanical vibrations was adequate and efficient to harvest macaw fruits;

The project methodology adapted permitted the development of an efficient conceptual device for the harvesting of macaw fruits;

The prototype constructed, in preliminary trials, proved feasible to be used as an alternative for mechanized harvesting of macaw fruits.

\section{Acknowledgments}

The authors thank the Conselho Nacional de Pesquisa $(\mathrm{CNPq})$ and the Fundação de Amparo a Pesquisa de Minas Gerais (FAPEMIG) for the financial resources for the implementation of the project.

\section{References}

BERTOLDI, T. L. Projeto informacional e conceitual de uma máquina para aplicação localizada de fertilizantes em pomares. 2013. Dissertação (Mestrado em Sistemas de Produção Agrícola Familiar) - Universidade Federal de Pelotas, Pelotas.

BOHN, E. Tablero de comando para la promoción de los biocombustibles en Paraguay. Santiago: Organização das Nações Unidos/Cepal, 2009. 108 p.

BRASIL. Ministério do Desenvolvimento Agrário MDA. Diretrizes e recomendações técnicas de boas práticas de manejo para o extrativismo do fruto da macaúba/bocaiuva (Acrocomia spp.). Brasília: MDA, nov. 2014. $52 \mathrm{p}$.

CARVALHO, K. J.; SOUZA, A. L.; MACHADO, C. C. Ecologia, manejo, silvicultura e tecnologia da macaúba. Viçosa, MG: UFV, 2011. 25 p. Available at: <http:// www.ciflorestas.com.br/arquivos/ d_b_b_15592.pdf $>$. Accessed at: 12 mar. 2016.

COELHO, A. L. de F.; SANTOS, F. L.; QUEIROZ, D. M. de; PINTO, F. de A. de C. Dynamic behavior of the coffee fruit-stem-branch system using stochastic finite element method. Coffee Science, Lavras, v. 11, n. 1, p. 1-10, 2016.
CUNHA, J. P. B.; MACHADO, T. A.; SANTOS, F. L.; COELHO, L. M. Perdas na colheita de tomate industrial em função da regulagem da colhedora. Pesquisa Agropecuária Tropical, Goiânia, v. 44, n. 4, p. 363-369, 2014.

INSTITUTO PARANAENSE DE ASSISTÊNCIA TÉCNICA E EXTENSÃO RURAL - EMATER. Manual do café colheita e preparo. Belo Horizonte: EMATERMG, 2016.

GODOY, M. H. P. C. Brainstorming. Belo Horizonte: Editora de Desenvolvimento Gerencial, 2001. 28 p.

HOUDE, S.; HILL, C. What do prototypes prototype? In: HELANDER, M.; LANDAUER, T.; PRABHU, P. Handbook of humane computer interaction. Amsterdam: Elsevier Science, 1997. N.62. 1582 p.

MANTOVANI, E. C. Sistema de produção. 6. ed., Sete Lagoas: Embrapa Milho e Sorgo, set. 2010. 10 p. Disponível em: <http://www.cnpms.embrapa.br/ publicacoes/milho_6_ed/colregula.htm>. Accessed at: 15 jan. 2017.

MONTOYA, S. G.; MOTOIKE, S. Y.; KUKI, K. N.; OLIVEIRA, C. M.; HONÓRIO, I. G. Registro da presença e danos causados por coleopteros em macaúba. Pesquisa Florestal Brasileira, Colombo, v. 35, n. 82, p. 159-162, 2015.

MOTA, C. S.; CORRÊA, T. R.; GROSSI, J. A. S.; CASTRICINI, A.; RIBEIRO, A. da S. Exploração sustentável da Macauba para a produção de biodiesel: colheita, pós-colheita e qualidade dos frutos. Informe Agropecuário, Belo Horizonte, v. 32, n. 265, p. 41-51, 2011.

NICKEL, E. M.; FERREIRA, M. G. G.; FORCELLINI, F. A.; SANTOS, C. T.; SILVA, R. A. A. Modelo multicritério para referência na fase de projeto informacional do processo de desenvolvimento de produtos. Gestão $e$ Produção, São Carlos, v. 17, n. 4, p. 707-720, 2010.

PAHL, G.; BEITZ, W. Projeto na engenharia: fundamentos do desenvolvimento eficaz de produtos, métodos e aplicações. São Paulo: Edgard Blucher, 2005. $411 \mathrm{p}$.

SANTOS, F. L.; QUEIROZ, D. M.; PINTO, F. A. C.; RESENDE, R. C. Frequency and amplitude of vibration on coffee harvesting. Revista Brasileira de Engenharia Agrícola e Ambiental, Campina Grande, v. 14, n. 4, p. 426-431, 2010.

SILVA, F. C.; SILVA, F. M.; ALVES, M. C.; FERRAZ, G. A. S.; SALES, R. S. Efficiency of coffee mechanical and selective harvesting in different vibration during harvest time. Coffee Science, Lavras, v. 10, n. 1, p. 56-64, 2015. 
SOMMERVILLE, I. Software engineering. $9^{\text {th }}$ ed. Addison: Wesley, 2010. 792 p.

VELLOSO, N. S. Propriedades físicas e comportamento dinamico do Sistema fruto-ráquila da macauba (Acrocomia aculeata). 2016. Dissertação (Mestrado em Engenharia Agrícola) - Universidade Federal de Viçosa, Viçosa, MG.

VERONESI, C. O.; SOUZA, C. M.; SERRA, A. P.; RAFULL, L. Z.; SILVA, C. J.; ROS, V. V. Economical feasibility of the harvesting and the processing of Jatropha curcas L. seeds in different stage of maturation. Semina. Ciências Agrárias, Londrina, v. 33, n. 6, p. 2047-2056, 2012.
VILLAR, F. M. de M.; PINTO, F. de A. de C.; SANTOS, F. L.; GROSSI, J. A. S.; VELLOSO, N. S. Elasticity modulus and damping ratio of macaw palm rachillas. Ciência Rural, Santa Maria, v. 47, n. 2, p. 1-6, 2017. Available at: <http://www.scielo.br/pdf/cr/v47n2/16784596-cr-47-02-20160289.pdf>. Accessed at: 13 feb. 2017.

YANG, M. C.; EPSTEIN, D. J. A study of prototypes, design activity, and design outcome. Design Studies, Amsterdã, v. 26, n. 6, p. 649-669, 2005. 